\title{
REDACTIONEEL
}

\section{Inleiding: Staat en toekomst van de bestuurskunde}

\author{
Haiko van der Voort \& Philip Marcel Karré
}

Geen thema ditmaal. Geen concept, methode of toepassingsgebied die het eerste gedeelte van dit nummer van Bestuurskunde samenbindt. De consequentie laat zich raden: de bijdragen aan dit nummer zullen een weerspiegeling vormen van de diversiteit die de bestuurskunde te bieden heeft. Bestuurskunde is nu eenmaal multidisciplinair en haar ideeën zijn relevant voor veel toepassingsgebieden. In dit nummer zullen we de overheid zien in vele facetten, bijvoorbeeld als handhaver van de wet, als krimpende organisatie, als open systeem voor externe adviseurs, als werkgever en als een geheel van verschillende organisaties.

Dit themaloze nummer start met een klassiek onderwerp, namelijk bezuinigingen binnen grote, publieke organisaties. De insteek van Schmidt is echter minder klassiek: de auteur gaat er van uit dat een deel van de topambtenaren die in 'hun eigen vlees' moeten snijden een achtergrond hebben in de private sector. Op basis van interviews met topambtenaren gaat hij na of er verschillen bestaan tussen de bezuinigende ambtenaren met een publieke achtergrond en hun lotgenoten met een private achtergrond. De relatie tussen grote overheidsorganisaties en de private sector komt ook aan de orde in de bijdrage van Van den Berg en zijn collega's. $\mathrm{Zij}$ richten zich op de aard en het belang van extern beleidsadvies en geven op basis van survey-onderzoek Nederlandse trends weer.

Schipper c.s. richten zich meer op semi-overheidsorganisaties op het operationele niveau. Zij geven op basis van documenten en interviews heel levendig weer hoe fragmentatie van organisaties de complexiteit van operationele activiteiten doet toenemen, in casu de ingebruikname van wissels voor het spoorvervoer. Ook De Bruijne en zijn collega's richten zich op het operationele niveau, maar beschouwen vooral private organisaties. De overheid treedt hier als toezichthouder op, die bedrijven hun eigen risico's ziet inschatten en beheersen. Op basis van interviews constateren de auteurs dat bedrijven schipperen tussen formele risicomanagementsystemen en meer informele mechanismen van risicobeheersing. Zij vragen zich vervolgens af hoe dit schipperen als norm te beschouwen is. Ook Margo Trappenburg ziet heil in een normatieve bestuurskunde. Zij beschrijft hoe loonfatsoen de afgelopen decennia is gedemoraliseerd en recentelijk geremoraliseerd, zij het voor slechts de top van de arbeidsmarkt. In haar essay beschrijft zij hoe de bestuurskunde een rol kan spelen in discussies over deze gedeeltelijke remoralisering van loonfatsoen. 
Grote verschillen, inderdaad! Er zijn maatschappelijk georiënteerde en meer management-georiënteerde bijdragen, er zijn beschrijvende en normatieve artikelen en zowel publieke, als semipublieke alsook private organisaties worden beschouwd op bestuurlijk en operationeel niveau.

Waar zijn de overeenkomsten? Het valt op dat er veel klassieke bestuurskundige thema's worden aangeraakt, zoals bezuinigingen, toezicht, coördinatie, beleidsadvies en werkgeverschap. Maar deze thema's worden vooral beschouwd tegen de achtergrond van schokkende, zo niet schokkerige, institutionele verschuivingen. Bezuinigende topambtenaren hebben steeds vaker een private achtergrond, externe beleidsadviseurs nemen een deel van het publieke werk over, voormalige overheidsorganisaties worden gesplitst en moeten hun activiteiten coördineren, toezichthouders zetten in op zelfregulering door bedrijven, en de publiek-private scheidslijn lijkt nog hard in de remoralisering van het loonfatsoen. De bijdragen geven allemaal een inkijk in een veranderende overheid ten tijde van hybridisering, fragmentatie en horizontalisering en laten zien wat een bestuurskundige benadering eraan bijdraagt deze te duiden en te begrijpen. Dit helpt niet alleen de bestuurskundige wetenschappers onder ons die bezig zijn al deze trends en ontwikkelingen te onderzoeken en er advies over uit te brengen, maar ook de bestuurskundige professionals onder onze lezers in hun zoektocht zich er productief toe te verhouden.

Behalve bij deze inhoudelijke bespiegelingen, staan wij vanaf dit nummer in een serie artikelen ook stil bij de ontwikkeling van de bestuurskunde als discipline op het snijvlak van theorie en praktijk. Als geïnstitutionaliseerd vakgebied is de bestuurskunde in Nederland nu ruim veertig jaar oud, als we de oprichting van de Vereniging voor Bestuurskunde in 1974 en de eerste zelfstandige studierichting in Twente in 1976 als startpunten nemen. Tijd voor een uitgebreide reflectie, met name ook omdat er vragen zijn die steeds terugkomen: Is het een eigenstandige discipline, dan wel een onderdeel van de politicologie, de juridische of de managementwetenschappen? En zou de bestuurskunde zich meer op de praktijk of juist op de pure wetenschap moeten richten?

Mede door de hybridisering, fragmentatie en horizontalisering van ons kenobject zijn ook het institutioneel kader van de bestuurskunde, de inbedding in het onderwijs en de manier waarop wij als bestuurskundigen onderzoek verrichten, aan het veranderen. Op universiteiten worden bestuurskundige vakgroepen gereorganiseerd (bijvoorbeeld aan de EUR) en zien we veranderingen in het opleidingsaanbod, waaronder de opkomst van stevige researchmasters.

Het bestuurskundeonderwijs aan hogescholen is aan het groeien, met bacheloropleidingen bij Avans, Saxion, NHL, de Haagse Hogeschool en de Hogeschool van Amsterdam en inmiddels ook masteropleidingen (zoals bij de HvA). Behalve bij hogescholen en universiteiten kunnen ambtenaren en anderen werkzaam in het openbaar bestuur voor hun verdere professionalisering ook terecht bij andere aanbieders, zoals bijvoorbeeld de Nederlandse School voor Openbaar Bestuur (NSOB). 
Ook in het bestuurskundig onderzoek zien we verschuivingen. Naast een toenemende internationalisering van het onderzoek, waarbij publicatie in Engelstalige tijdschriften gericht op een academisch vakpubliek belangrijker geworden is dan in de eigen taal en/of publicaties die zich net als Bestuurskunde ook richten op de professional, zien we ook een 'verwetenschappelijking' van de gebruikte methoden. Zo zijn bijvoorbeeld bestuurskundige experimenten in opkomst en wordt er ook versterkt aandacht geschonken aan kwantitatief onderzoek. Het bestuurskundig onderzoek innoveert methodologisch, schuift op naar de randen van de oude discipline, maakt gebruik van inzichten uit andere, zoals de psychologie en economie, maar verliest toenemend zicht op de klassieken en verdwijnt naar de rand. En ook wat het onderzoek betreft zien we een verbreding. Met name wat toepassingsgericht onderzoek betreft, zijn universiteiten al lang niet meer de enige aanbieders. Ook de lectoraten van hogescholen en denktanks als de NSOB zijn in deze markt actief.

Bestuurskundeonderwijs en -onderzoek kunnen op meer plekken dan ooit genoten worden. Deze verbreding en opkomst van nieuwe spelers in de markt, zoals hogescholen, hebben er wel toe geleid dat er al een tijdje in de bestuurskundige gemeenschap een discussie wordt gevoerd over wat voor soort beest de bestuurskunde nou écht is: is het een wetenschap, die gediend is bij een academische benadering in het onderwijs, of inderdaad meer een professie, die zich zou moeten richten op toepassing in de praktijk van het openbaar bestuur?

Aldus: waar staat de bestuurskunde voor en wat is de toekomst voor ons vakgebied? Het afgelopen jaar heeft de Vereniging voor Bestuurskunde (VB) hier een aantal bijeenkomsten aan gewijd. Wij verdiepen en verbreden de discussies die daar gevoerd zijn, door vanaf dit nummer een serie artikelen te plaatsen, die hier nader op ingaan. Wij beginnen met een artikel van Gadellaa, Curry en Van de Walle over de vraag hoe bestuurskundig de Nederlandse bestuurskunde nou eigenlijk (nog) is. Dit artikel beschrijft hoe bestuurskundigen zelf de discipline en de ontwikkelingen erin zien, op basis van een survey onder Europese bestuurskundigen. In het winternummer plaatsen wij vervolgens een artikel van Veer en 't Hart dat verslag doet van de door de VB uitgevoerde vijf debatsessies over de ambities en prestaties van het vakgebied. De auteurs maken de balans op en schetsen een aantal centrale uitdagingen voor de komende decennia. In 2016 zullen verdere bijdragen in Bestuurskunde nader op deze uitdagingen ingaan. Wij hopen dat hierdoor een brede discussie van de grond zal komen over staat en toekomst van de bestuurskunde en nodigen onze lezers nadrukkelijk uit daaraan mee te doen. 